\title{
Research Process for Selecting a Theoretical Framework and Bibliometric Analysis of a Theme: Illustration for the Management of Customer Service in a Bank
}

\author{
Leonardo Ensslin'1, Ademar Dutra1, Sandra Rolim Ensslin², Leonardo Correa Chaves², \\ Vinicius Dezem1 \\ ${ }^{1}$ Universidade do Sul de Santa Catarina (UNISUL), Florianópolis, Brazil \\ ${ }^{2}$ Universidade Federal de Santa Catarina (UFSC), Florianópolis, Brazil \\ Email: leonardoensslin@gmail.com
}

Received 18 May 2015; accepted 27 June 2015; published 30 June 2015

Copyright (C) 2015 by authors and Scientific Research Publishing Inc.

This work is licensed under the Creative Commons Attribution International License (CC BY).

http://creativecommons.org/licenses/by/4.0/

(c) (i) Open Access

\begin{abstract}
Globalization has brought to institutions greater competitiveness and visibility to products and services, which means that consumers started to be more demanding and take advantage of the best references for establishing standards for their care. The banking industry fits in this context, and to remain competitive they seek new developed management procedures to better serve their customers. The objective of this study is to demonstrate to the theme fragment bank funding and resource loans management, with an emphasis on customer relationship, how to select a bibliographic portfolio and perform their bibliometrics, in order to highlight the most recognized scientific contributions on the subject. This work is characterized as exploratory-descriptive, of theoretical-illustrative nature, using ProKnow-C-Knowledge Development Process-Constructivist as an intervention tool. The bibliographic portfolio with 13 articles was generated by the development process; the Journal of Financial Economics showed the highest impact factor to scientific community at both bases, JCR and SJR. Bank, Risk and Lending Outcomes were the main appellant keywords and the most prominent authors were Hans Degryse with two articles in the portfolio, article of Bank Governance, Regulation and Risk Taking, written by Luc Laeven and highest scientific recognition of Ross Levine.
\end{abstract}

\section{Keywords}

Assessment, Management, Performance, ProKnow-C, Bibliometry

How to cite this paper: Ensslin, L., Dutra, A., Ensslin, S.R., Chaves, L.C. and Dezem, V. (2015) Research Process for Selecting a Theoretical Framework and Bibliometric Analysis of a Theme: Illustration for the Management of Customer Service in a Bank. Modern Economy, 6, 782-796. http://dx.doi.org/10.4236/me.2015.66074 


\section{Introduction}

The expansion of credit operations, in Brazil, after the Real Plan (1994) was comprehensive in various segments of the economy; however, the operations of credit to private individuals were the ones that grew the most in recent years. The consolidated information, disclosed by the Central Bank of Brazil, for each type of credit of the national financial system shows that, already at the beginning of the year 2001 the total balance of operations granted to individuals has represented a volume of more than $50 \%$ of the total balance of operations granted to legal persons [1].

The banking function has been consolidated and expanded exponentially in the last decade, on the one hand, because of the development of means of communication that allowed banks to access quickly and reliably the life and the risks of potential customers, and on the other hand, because of the need of banks to raise funds of these same users. In the current situation of the developed countries, $60 \%$ of the population make use of banks, both to obtain credit and to invest, evidencing the relevance of this customer-bank integration [2]-[9].

The national economic policy has been expansionary in recent years, especially in the market of loaning and financing. Through the reduction of interest rates in public banks, the federal government has stimulated competition in the market and has reduced the cost to the customer, in the moment that takes third-party resources [2] [5] [10].

Not only the credit market was influenced, but also it created the bank portability, instrument by which individuals can receive their proceeds, related to salary in a financial institution of their choice. In addition, the portability includes migration of loaning or financing and transfer of values applied in supplementary pension [2] [3] [10]-[12].

Having in view that the market is more and more competitive and competition tends to be stimulated by regulatory bodies, it is necessary to adopt strategies that generate differentiation before the market, thereby promoting lasting long-term relationships.

It is noteworthy, too, that in the banking sector, the relationship marketing is based on unique factors to the reality of this sector, for example, the fact of wishing lasting relationships as a way to monitor the borrowers or to produce information for the credit. Another point in favor of the adoption of strategies for relationship marketing, in the banking sector, is the fact that the great majority of employed people receive their salaries through banking institutions. This makes possible for banks to begin a relationship with customers that can be profitable [4] [13]-[19].

Once the problem framework relative to the context to the theme fragment banking management of funding and loaning of resources is established, with emphasis on the relationship with the customers, we can advance to the central concern of this work. The need to establish a process for evaluating and improving the bank funding and resource loans management by its turn requires the construction of a theoretical framework that reflects the most relevant and up-to-date academic knowledge in this field. However, the process of finding that knowledge must start from the recognition that the academic knowledge is widely dispersed in a variety of academic basis. This widely spread knowledge will ultimately need to be collected in a structured process for the selection of studies with high academic relevance for the context of the study, in order to provide a robust theoretical framework. This raises the research question: how to select references that have high academic relevance and that simultaneously are directly aligned to the context of the management of customer service in a bank in what concern the relationship with customers in the funding and resource loans management activities and perform their bibliometrics, in order to highlight the most prominent authors, articles, periodicals and keywords on the subject.

To answer the research question, the present work aims to select references that have high academic relevance and that simultaneously are closely aligned of the subject banking management of funding and loaning of resources, with emphasis on the relationship with customers, and perform their bibliometrics analysis to identify the selected theoretical framework, seeking to identify the authors, the periodicals, the articles and the keywords that are most prominent in this area of knowledge.

The research shall use the process ProKnow-C (Knowledge Development Process-Constructivist) as intervention instrument [19] [20]-[23].

To achieve the proposed objective, we have developed the following specific objectives: 1) selecting a Bibliographic Portfolio-BP aligned to the subject banking management of funding and loaning of resources, with emphasis on the relationship with customers, in the international databases; 2) performing a bibliometric analy- 
sis of bibliographic portfolio and its references, in order to know the main journals, articles, authors and keywords on the subject of interest.

This work is structured in four sections. The first is presented here by the introduction, then the exposure of research methodology, the results of the research, and, later, in the third part, the final considerations; finally, we present the references used in the preparation of this study.

\section{Research Methodology}

The methods and procedures to be applied depend very much on the subject, the type of research (qualitative or quantitative), available resources, among other factors. It should be noted, however, that they must guide the thinking of researchers and help to understand not only the result of the investigation, but also the process of research [24].

This section aims at presenting the theoretical framework on the subject, the methodological framework and ProKnow-C the Instrument of intervention used for the development of this study.

\subsection{Theoretical Framework}

The studies related to economic finances have demonstrated the importance of adopting a stable financial system, to ensure the sustainable growth of nations. Within these systems, more active bodies, responsible for maintaining the active in the economic cycles are banks, although acting as any company that, in the process of interaction with the environment, obtain the resources to turn them into products or services

What distinguishes banks from the other companies is the ability that they have to promote economic development, mainly from third party resources to perform their basic functions. To capture and apply these resources, however, it is necessary to emphasize the need for these institutions of gaining confidence, on the part of customers to ensure the bank's stability [6] [25]-[27].

A series of studies, many in international context, have evaluated if the credit decisions improve or worsen when customers and banks are connected in some way. From the moment that bank and customer perform more than a commercial exchange with success, there is a tendency for the long-term relationship, in which borrower and financial institution can obtain advantages, the first may seek lower costs in pursuit of money, or higher rates when it comes to applications; the second is able to obtain important information on the habits of the customer, data that competitors do not have [7] [10].

A bank-customer relationship begins when the person buys, for the first time, a banking product. The average duration of the relationship is approximately seven years. During this period, to try the banking products and enjoy the flexibility of the bank, the person has to maintain and fulfill implicit contracts. In the meantime, the bank takes to collect private information about the customer, in order to tailor its products, and seek the loyalty of the same. In the bank sector another success factor is the use of multi commercial agencies in critical locations areas in order to provide customer with quality and at the same time best accessibility. Strategies like this provide the basis for the creation of a long-term relationship [5].

The short-term loans has become an excellent opportunity to build relationships with the customer to the financial institutions. It is important to emphasize the need for analysis of credit risk in the release, in order to minimize bad debt and promote the profitability of the loaning institution. It is worth noting, also, that the initial relationship is not a guarantee for new releases; they depend on the financial potential of the customer [2] [8].

As can be observed the banking management of funding and loaning of resources, with emphasis on the relationship with customers is in the heart of banking success.

\subsection{Methodological Framework}

To achieve the objectives in this work, we carried out a scientific research, by means of methodological procedures. According to Gil [28], the research has a pragmatic character, constituting a formal and systematic process of scientific method development. The fundamental objective of the research is to discover answers to problems by employing scientific procedures.

The present study, in a first moment, is characterized as exploratory, develops the knowledge of the researcher through the reflection that this makes and by its active participation in the course of the proposed process, since the definition of the research axes until when selects and delimits what analyze in the sample of the portfolio articles. 
The inductive logic is that stimulates the analysis by considering what is known by the researchers is still focused on empirical models, in that the problem has still not been adequately scientifically explored [29]. The generation of knowledge occurs in proportion to the steps defined in ProKnow- $C$, before the analysis of the subject alignment, reading articles and research on the state of the art.

The source of data collection is primary and secondary ones [29]. The primary data comes from delimitations established by authors/researchers throughout the process of Bibliographic Portfolio selection. The secondary data were obtained from the results of the Bibliographic Portfolio article results analysis and the references contained in the articles of the Portfolio.

This work can also be considered as qualitative and quantitative, since, in the first step, there was a qualitative selection to identify articles of bibliographic portfolio; and, in the second step, when data were analyzed as the number of publications and authors citations [16] [20].

In terms of its results, this research is classified as applied, since the knowledge generated can be used for, from journals, articles, authors and keywords, direct for further study to understand the potential and opportunities in the state of art and, thus, guide the next steps of the research [19].

\subsection{Intervention Instrument ProKnow-C}

The context in which the researcher is inserted is a determining factor in the selection process of delimitations, which are also vulnerable to the means of dissemination of already carried out and published researches. Even in this sense, it is clear that the search for relevant articles, that build knowledge is increasingly difficult, due to the quantity of information that is available in the national and international literature, scattered in more varied sources of research [15]-[17] [19].

The intervention instrument used was ProKnow-C, which began to be developed at the beginning of 2000's, in the Laboratory of Multicriteria Methodologies in Decision Support (LabMCDA), linked to the Engineering Department of Production and Systems at Federal University of Santa Catarina, with the aim to overcome the lack of a structured process for the selection of a bibliographic referential with scientific recognition, and its analysis for a given subject.

The researchers realized that the materials informing the review of the state of art of their publications could be questioned about the alignment and the relevance of the content, related to the purpose of the research and the completeness of the search for these materials. In 2007 and 2008, appeared the first versions, and, in 2009, the first publications, reaching, in 2010, the first international publication. Currently, ProKnow-C has more than 36 publications, consolidating this instrument as an important research tool for the academic community [15]-[17] [20] [21]-[23].

ProKnow-C process is divided into 04 main steps: 1) selection of bibliographic portfolio; 2) bibliometric analysis of portfolio; 3) systemic analysis; and 4) definition of the research question and its objectives. The following Figure 1 presents a macro view of ProKnow-C [6] [7]. ProKnow-C has several publications in journals, consolidating itself as a process for mapping of knowledge, according to the boundaries and motivations of the researcher as can be seen in the applications of ProKnow-C in [15] [17] [18] [20] [22] [24] [30] [31], applying all of the structure proposed in Figure 1.

In this study, two stages of the Bibliographic Portfolio development and its bibliometric analysis will be presented, then, to build part of the necessary knowledge about the subject raised. To better illustrate the structure of the research Figure 1 was generated.

For this research, the steps 1) and 2) of Figure 1 were developed, i.e., the articles that comprise the Portfolio Bibliography (BP) were selected based on the interests and the delimitations of the researchers, and then the bibliometric analysis was held, in which the articles, authors, journals and the keywords of BP and its references were highlighted. Steps 1) and 2) of Figure 1 are presented in next section.

\section{Results Found}

This section presents the procedures followed and the results of the search process, which resulted in the identification of Bibliographic Portfolio aligned to the subject bank of funding and loaning resources with emphasis on the relationship with the customer, according to the perception of the authors, and with scientific recognition and the bibliometry of this Portfolio, which allowed to evidence the journals, articles and authors, in addition to the keywords. As the established period, this research was conducted in the months of October and November 2014. 


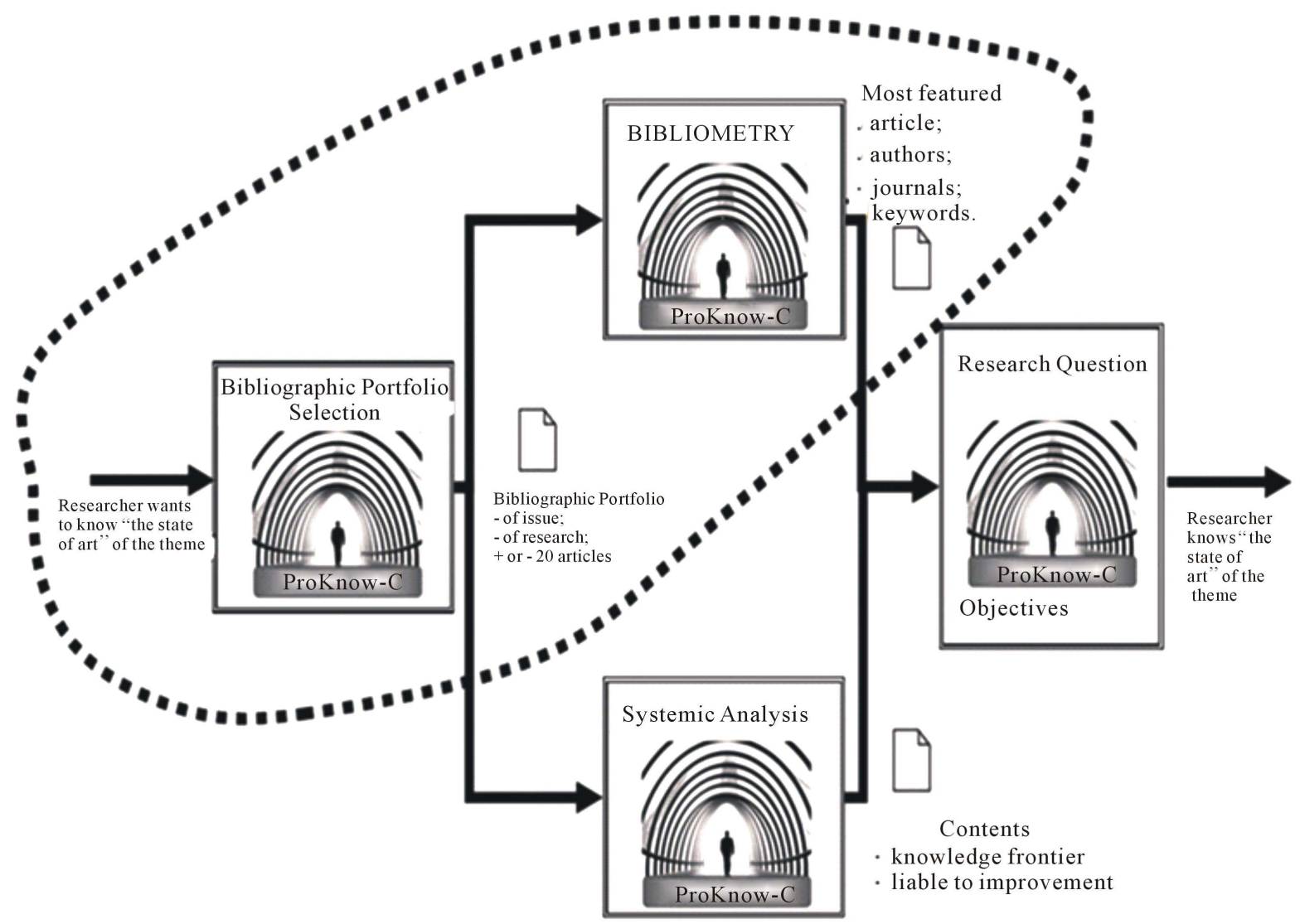

Figure 1. Steps of the methodology applied in the article. Source: [15].

\subsection{Selection of Bibliographic Portfolio}

The first step in the process for forming the Bibliographic Portfolio of the desired subject, according to ProKnow- $C$ process, is divided into two main phases: 1 ) selection of raw articles database; and 2) the filtering of articles database.

The selection of raw articles database is subdivided into four stages, which are: 1) definition of keywords; 2) definition of databases; 3) search for articles in the databases with the keywords; and 4) application of adherence test of keywords.

The second phase, articles database filtering is subdivided, in turn, in five steps: 1) elimination of repeated articles; 2) alignment by reading of the title; 3) alignment as the scientific recognition; 4) alignment by reading the abstract; and 5) alignment by full reading of articles.

\subsection{Selection of Gross Articles Database}

The step of selecting the gross articles database begins with the definition of the research axes, carried out according to the perceptions of the researcher. The research axes represent the dimensions that researchers consider necessary and sufficient to be contained in the subject to be searched. This delimitation explains why, in ProKnow-C, each theme is singular and represents a fragment of the subject under investigation [15] [17] [18] [20] [22] [24] [30] [31].

In order to develop the process of selecting the Gross Articles Database, the researcher defines its axes of research, according to his/her perception of the selected subject. The initial axis encompasses the market niche that you want to know, in this study the commercial banks; the second and third axes are directly related to the subject of work. They are: management and credit. The axes of the search correspond to the areas of knowledge that in the judgment of the researcher explains in sufficient form the fragment of the theme that he wants to study [16] [19] [23] [32]-[34]. 
Built the step of defining the axes, the researcher initiates the formation of keywords.

Definition of keywords: For axis 1, related to market niche that is studied, it was defined the keywords: "management", "performance", "assess" and "evaluation". In axis 2, it is the word "bank", and closing, the axis three is composed by "credit", "application", "risk" and "Insurance". All the times that such words were released in databases they were highlighted with quotation marks, in order to select or verbal substantive variations of words, as well as to promote research with parameter in the title of the articles. The keywords to search for articles consisted of keywords combination of each axis. Thus, each keyword to be used in the search contains, necessarily, the three lines of research and, therefore, the dimensions representing the subject, according to the perception of the authors/researchers.

Definition of databases in which the research will be applied: The selection of keywords and the axes of research done, the next step focuses on definition of databases for performing the research, having in view that these sample is established from the "Portal de Periódicos da CAPES" and are aligned to the area of study knowledge, in which the Applied Social Sciences are present. The bases chosen were ISI Web of Knowledge and Scopus, which represent a large number of periodicals in line with the subject.

Search for articles in the databases with the keywords: From the keywords, as defined at the beginning of the study, the research was carried out in databases, recalling that the search was always linked to: the title of articles; the abstract; and the keywords. There were a total of 12,753 articles, published between 2003 and 2014, (Figure 2).

Performing the test of keywords adherence: From the raw Portfolio found, three articles, with title aligned, were chosen, with the aim of checking their keywords and identify or not the need for possible changes, in order to increase the efficiency of the search. It was found the alignment of keywords with the subject, thus avoiding the amendment of some, or inclusion of new ones.

The next step is illustrated in Figure 3 and Figure 4, involving the filtering of articles.

Made the identification of the items in the database, the process of filtering is initiated, taking into account aspects such as the presence of repeated articles (filter of redundancy), alignment of the title with the subject, alignment of the abstract with the subject and availability of free articles on CAPES bases.

Taking as a starting point the gross Bibliographic Portfolio, composed by 12,753 articles, the file manager EndNote was used to check the redundancies. 4731 redundant articles were found, i.e., with the same title and structure, being only published in the two databases, leaving 8022 articles for the next step-the reading of title, in order to identify the alignment.

From the reading of these titles, it was realized that many were not linked to the proposed subject due to the amplitude of some keywords. In this way, it was found 405 articles aligned with the research subject by title, eliminating 7617 else.

The next step involved the consultation on Google Scholar site, which aims to find the number of citations in other studies of articles, thus generating the degree of scientific recognition, being possible to identify that $13 \%$ of articles represent $80 \%$ of the citations. Translating such expressions in numbers, 51 articles were treated separately and gave rise to the " $\mathrm{K}$ " repository. The other 354 articles, classified with title aligned and with potential recognition, formed the "P" portfolio.

The articles of the " $\mathrm{K}$ " portfolio had their abstracts read and there was a further cut, taking into consideration

\begin{tabular}{|l|l|l|l|}
\hline & AXIS 1 & AXIS 2 & AXIS 3 \\
\hline 01 & "Management" & "Bank" & "Credit" \\
\hline 02 & "Performace" & & "Application" \\
\hline 03 & "Assess" & " $"$ & "Risk" \\
\hline 04 & "Evaluation" & & "Insurance" \\
\hline
\end{tabular}

Figure 2. Keywords for the study. Source: authors’ research. 


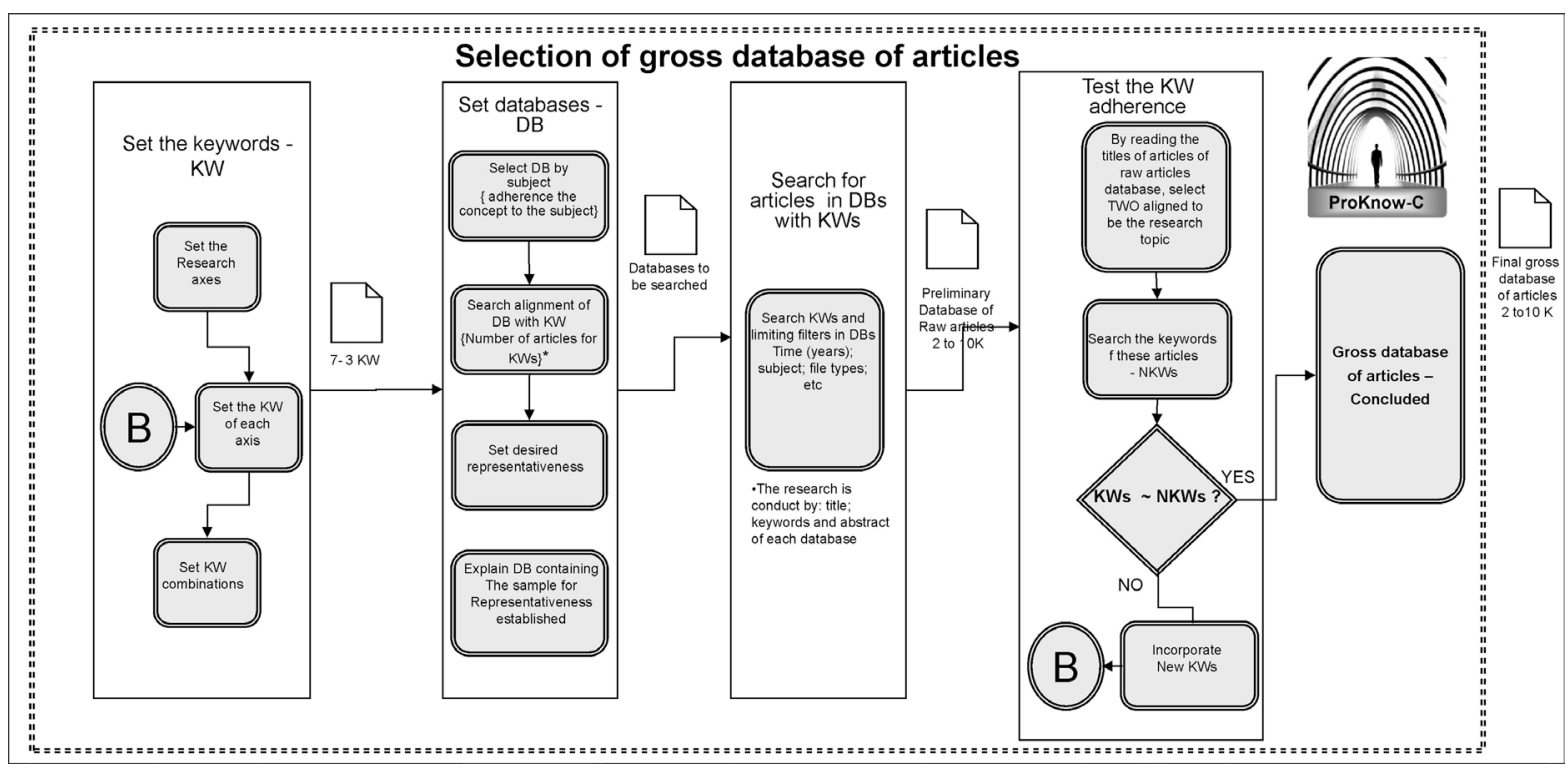

Figure 3. Steps in the selection phase of the gross articles database to form the initial Bibliographic Portfolio. Source: [15].

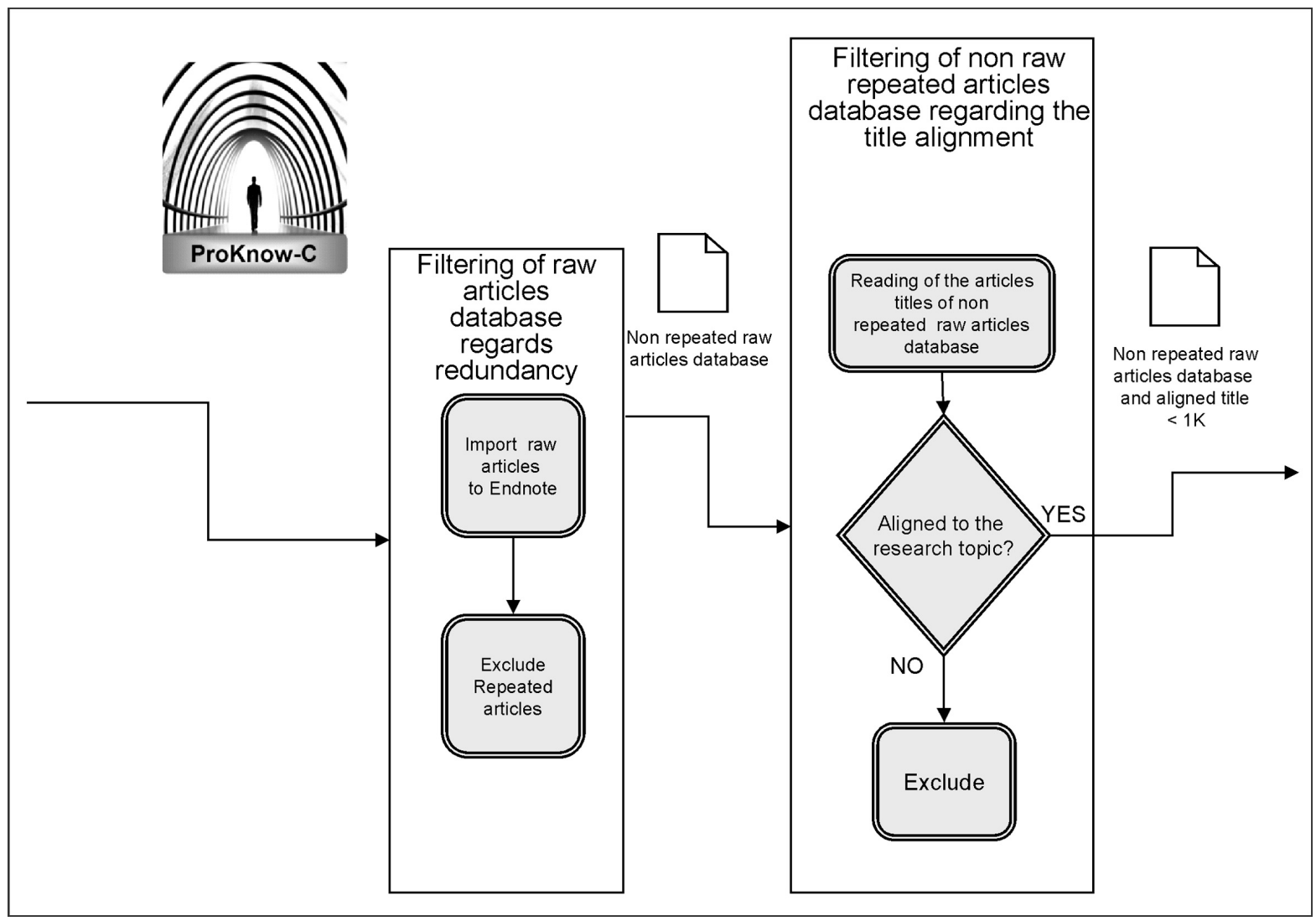

Figure 4. Processes of articles filtering. Source: [15].

the alignment of the subject, creating the database of not repeated articles, with title and abstract aligned and scientific recognition, here identified as "A" repository, which contained 12 articles. From this database of articles, it was also set up a database of authors, characterized as "BA".

"P” repository, composed by articles with title aligned and with potential recognition, was again analyzed. 
Articles with authors present in BA, and those with three or less years of publication and therefore less time to be cited, had their abstracts read, in order to identify works aligned with the research subject. Four articles were found that, according to the perception of the authors, had their abstracts aligned to the subject (Figure 5).

Summing the 12 items in "A" portfolio with 4 retrieved in the reanalysis, 16 articles were obtained. Further, we tried to obtain the full version of these 16 articles, and it was found that 4 were not available in the databases of free way, so they were eliminated from the process. Continuing the filtering process, the 12 articles available were read in full, all of which were considered aligned, ending the filtering process with a portfolio of 12 items.

This portfolio of 12 articles represents the publications aligned to subject bank management of funding and loaning resources, with emphasis on the relationship with the customer, as perceived by the authors/researchers of this work and with scientific recognition (Figure 6). The process ProKnow- $C$ now conducts a further step of checking the existence of any article aligned and with great scientific recognition that, in some of the stages of the process, has been omitted. This step is called "Test of Bibliographic Portfolio Representativeness", and will be presented below.

If there is any article of high impact in subject, necessarily it will be contained in the references of the selected portfolio. Thus, in this step, the references of the articles that make up the Bibliographic Portfolio were analyzed. The articles were organized in Microsoft Excel spreadsheet and, with the help of Google Scholar, the number of each article citation was searched. Then the articles were placed in decreasing order of number of citations and the most cited ones were analyzed for alignment.

Of these, one article was selected to compose the Bibliographic Portfolio (Relationship Lending: A Survey of the Literature). This is an article with 187 citations and, therefore, with scientific recognition and aligned with the subject of study. In this way, the Bibliographic Portfolio was composed by 13 articles, as shown in Table 1 .

\subsection{Bibliometric Analysis}

The next step in ProKnow-C consists in emphasizing the parameters of Bibliographic Portfolio (13 articles) and their references (344 articles) for the subject "banking management of fundings and loanings resources with emphasis on the relationship with the customer". The following parameters were analyzed: 1) relevance of journals; 2) recognition of scientific articles; 3) most prominent authors; 4) most used keywords; and 5) analysis of impact factor of BP journals.

The first parameter to be analyzed is the relevance of the periodicals in the Bibliographic Portfolio and in their reference. From the 13 articles that comprise the Bibliographic Portfolio, journals that stood out were Journal of Banking \& Finance, and Journal of Financial Economics, each one with 2 articles registered.

In the Bibliographic Portfolio references 18 journals were found. Journals Journal of Finance, with 28 publications; Journal of Banking and Finance, with 26 publications; and Journal of Financial Economics, with 24 publications, are the most present journals in the Bibliographic Portfolio references (Graph 1).

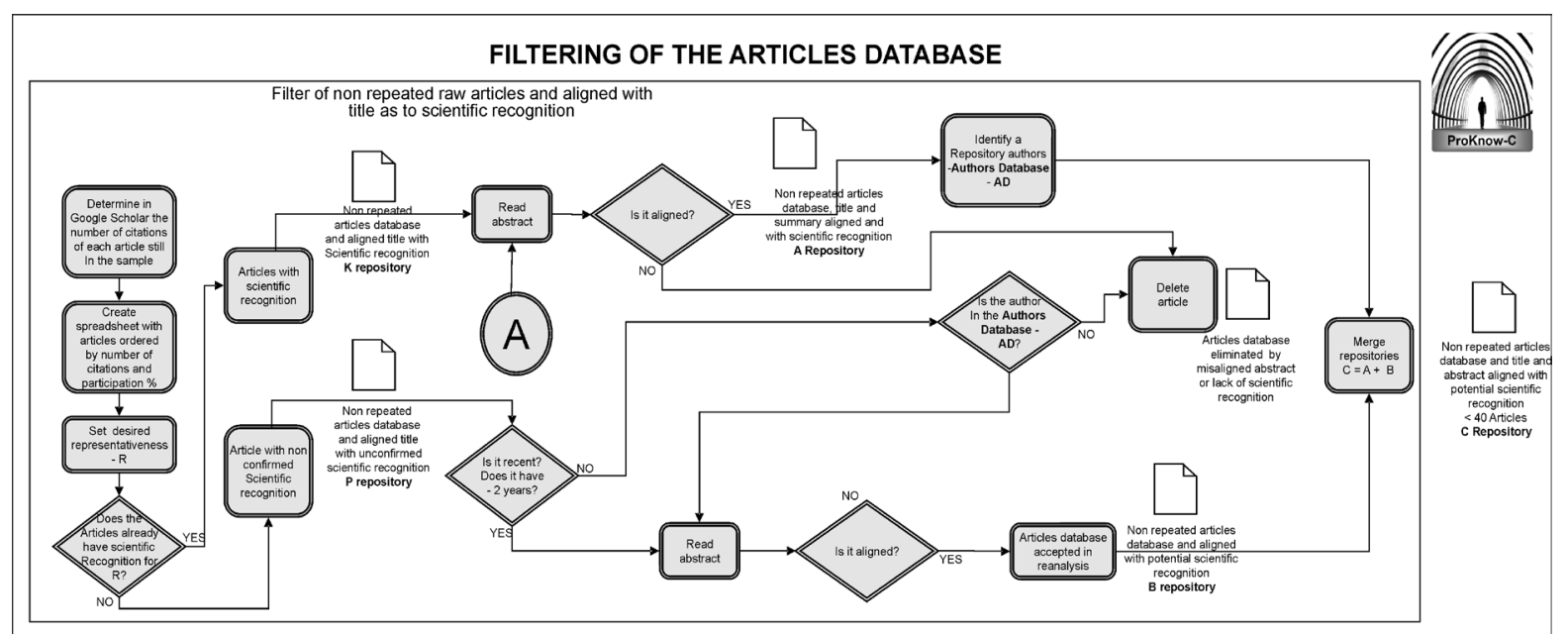

Figure 5. Processes of articles filtering. Source: [15]. 


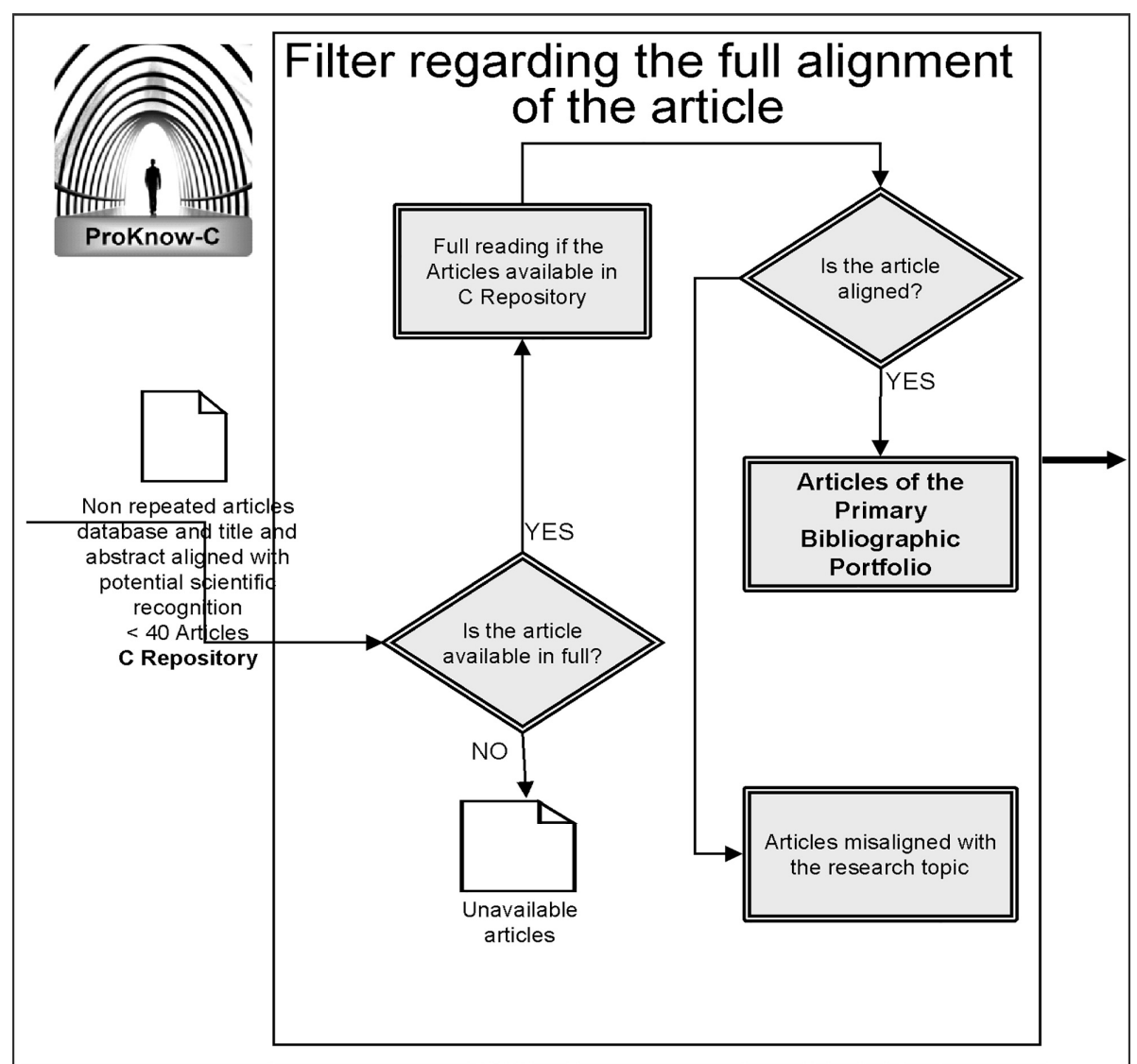

Figure 6. Step of filtering phase of the articles database. Source: [15].

\section{Table 1. Bibliographic portfolio articles.}

1 Albertazzi, U. and Gambacorta, L. (2009) Bank profitability and the business cycle.Journal of Financial Stability. [11]

Cebenoyan, A. S. and Strahan, P. E. (2004) Risk management, capital structure and lending at banks. Journal of Banking and Finan. [10]

3 Crook, J. N., Edelman, D. B. and Thomas, L. C. (2003) Recent developments in consumer credit risk assessment. European Journal of Operational Research. [2]

4 De Jonghe, O. and Vennet, R.V. (2008). Competition versus efficiency: What drives franchise values in European banking? Journal of Banking \& Finance. [3]

5 Dean, A. M. (2007) The impact of the customer orientation of call center employees on customers' affective commitment and loyalty. Journal of Service Research. [4]

6 Degryse, H. and Ongena, S. (2007) The impact of competition on bank orientation. Journal of Financial Intermediation. [5]

7 Degryse, H. and Ongena, S. (2008) Competition and Regulation in the Banking Sector.

Handbook of Financial Intermediation and Banking. [6]

8 Distinguin, I., Rous, P. and Tarazi, A. (2006) Market discipline and the use of stock market data to predict bank financial distress. Journal of Financial Services Research. [7]

9 Elyasani, E. and Goldberg, L. (2004) Relationship lending: a survey of the literature. Journal of Economics and Business. [8]

10 Engelberg, J., Gao, P. and Parsons, C. A. (2012) Friends with money. Journal of Financial Economics. [14]

11 Gertler, M., Kiyotaki, N. and Queralto, A. (2012) Financial crises, bank risk exposure and government financial policy. Journal of Monetary Economics. [9]

12 Laeven, L. and Levine, R. (2009) Bank governance, regulation and risk taking. Journal of Financial Economics. [26]

13 Medina, R., Puertas, M. and Selva, M. L. Credit scoring analysis, Revista De Administração De Empresas. [12]

Source: the survey data, 2013. 
The journal Journal of Financial Economics is present in 24 articles (Chart 1), in addition it is the only journal that appears with two articles in the Bibliographic Portfolio, therefore it was considered as the most prominent one, followed by the journals Journal of Finance and Journal of Banking and Finance.

The second aspect to be analyzed, refers to scientific recognition of articles in the Bibliographic Portfolio and its references. In BP, the most cited work was Bank governance, regulation and risk taking, written by Laeven, Luc Levine, Ross, published in 2009, in Journal of Financial Economics, with 578 citations. Even as a highlighted article, it is Risk management, capital structure and lending at banks, developed by Cebenoyan, A. S. Strahan, P.E, published in 2004, in Journal Of Banking and Financial, with 301 citations. Another important work is Credit Scoring Analysis, written by Medina, Rosa Puertas, Selva. Maria Lueza Marti, published in Magazine of Administration and Business, in 2013, with 278 citations (Graph 2).

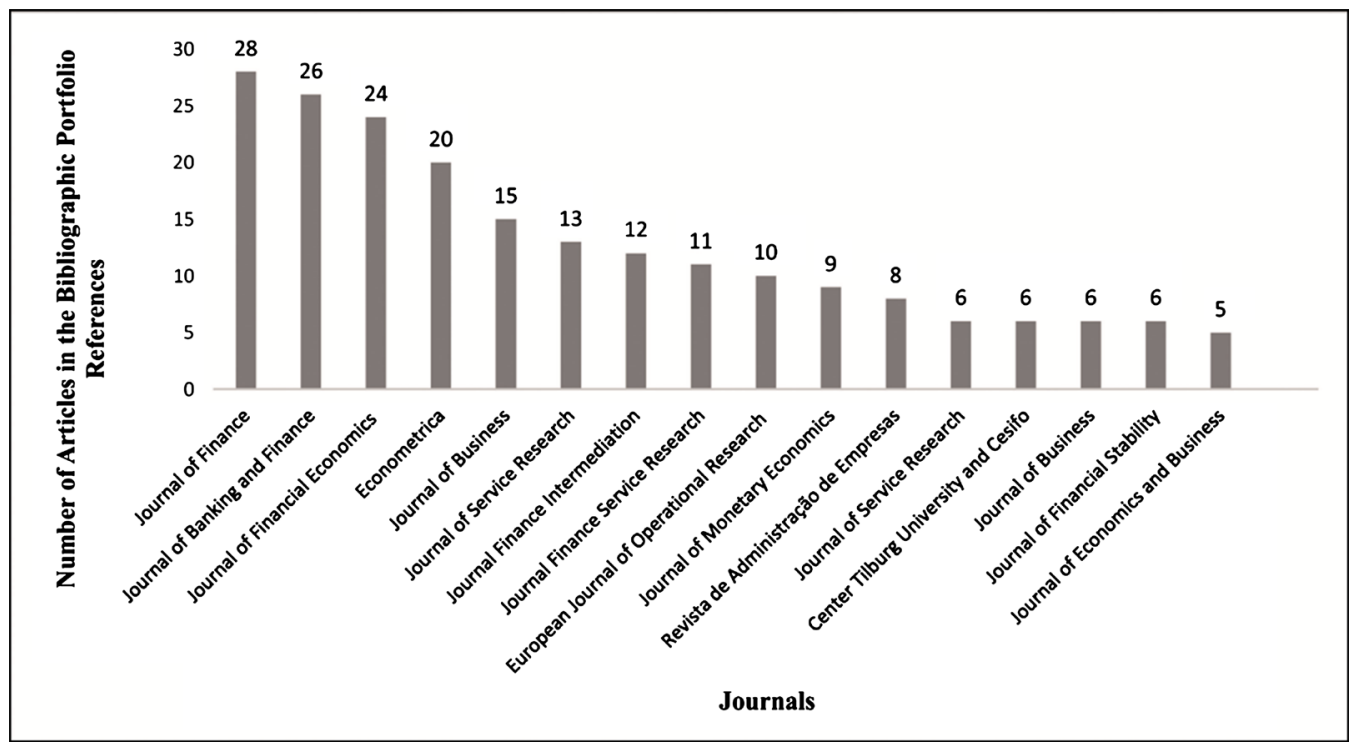

Graph 1. Highlighted journals in BP references. Source: elaborated by the authors with the survey data, 2013.

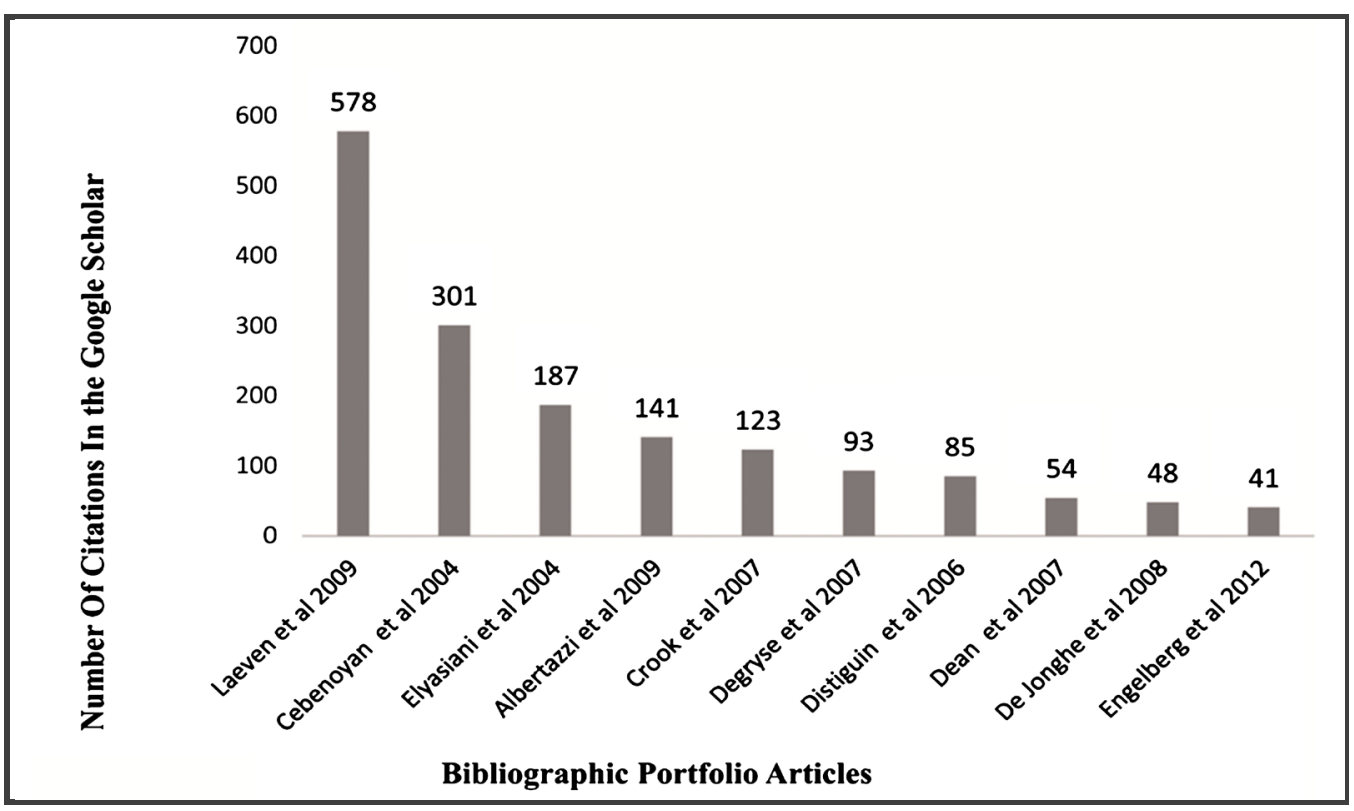

Graph 2. Relevant articles of the bibliographic portfolio. Source: elaborated by the authors with the survey data, 2013. 
The third parameter to be analyzed is the prominent authors in articles of the Bibliographic Portfolio and in their reference. The authors who make up BP, Degryse stands out, with two publications among the 13 articles selected for this study. Degryse stands out also in the scientific community, for works related to the area of finance and banking, as the Graph 3 presents.

The previous Graph 4 informs about the authors present in the references of the articles, in which the following stand out: J. P. Hughes, which appears with three articles; followed by: A. Saunders, A. W. The Boot et all, J. C. Stein, J. H. Boyd, L. Laeven, Ra Fisher, R. C. Merton, which appear with two articles.

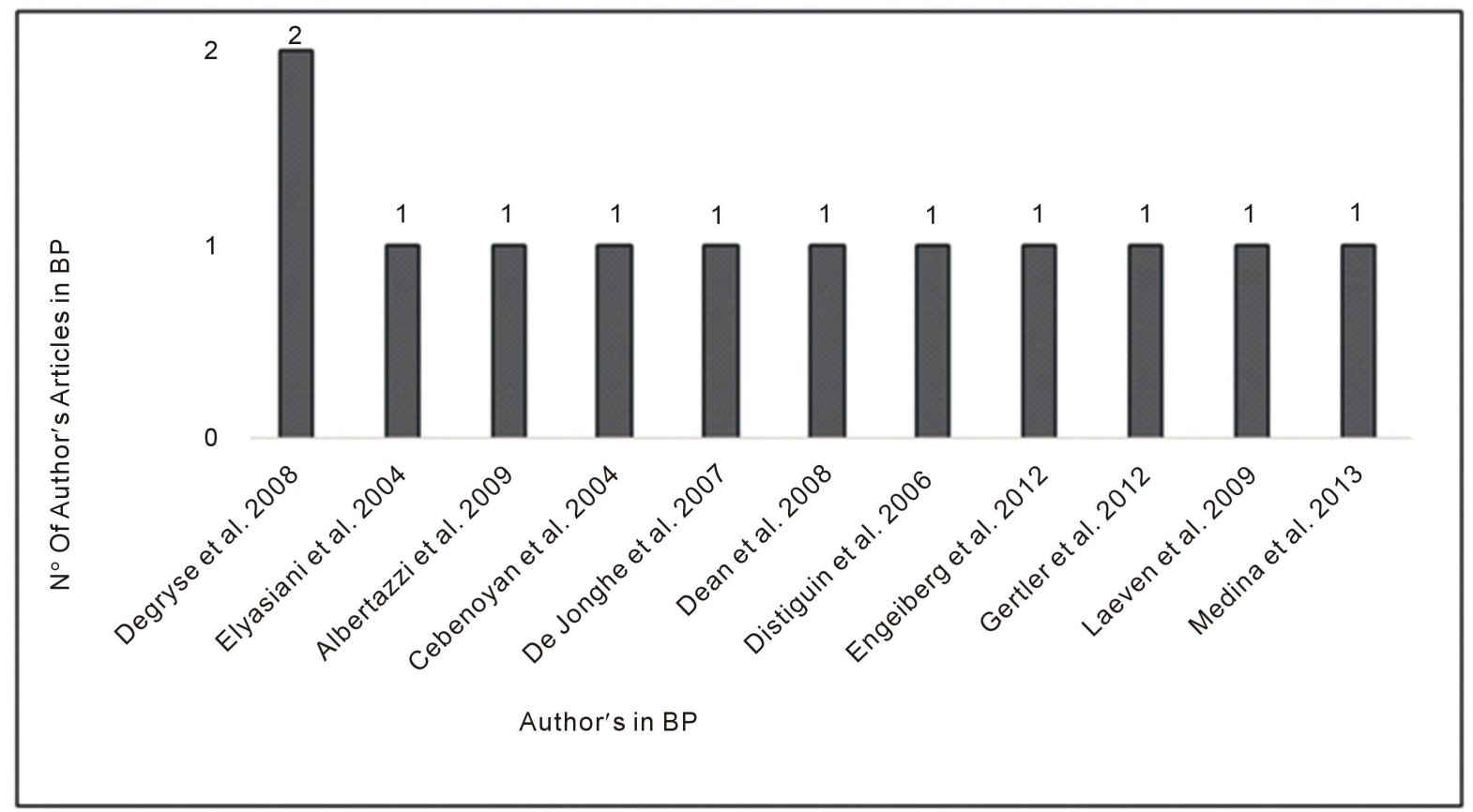

Graph 3. Prominent authors in Bibliographic Portfolio-BP. Source: elaborated by the authors with the survey data, 2013.

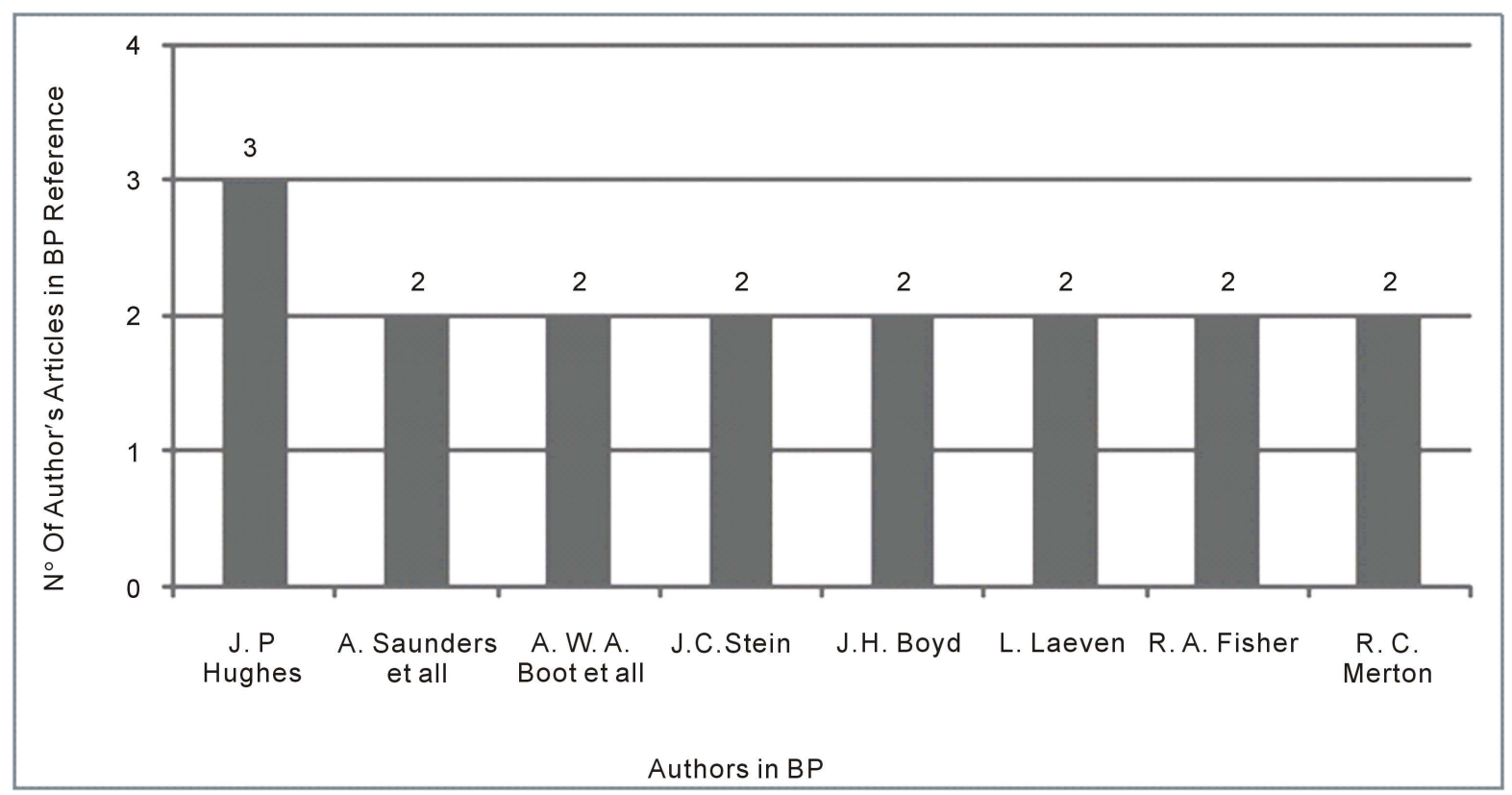

Graph 4. Prominent authors in Bibliographic Portfolio-BP references. Source: elaborated by the authors with the survey data, 2013. 
The fourth parameter to be analyzed is Impact Factor of the Journals of the Bibliographic Portfolio. To analyze the performance of the journal before the scientific scenario, it is necessary to check the impact factor, which shows the number of citations in the last two years. In this study, the periodicals were consulted in databases ISI Web of Knowledge and Scopus, each one of which has its own methodology, being called JCR and JRS, respectively (Graph 5 and Graph 6).

In ISI, the highlighted journals in the Portfolio and in the impact factor are presented in Graph 6 where it is possible to identify that the journal with the highest rate is the Journal of Economics and Finance.

Comparing the presented data, it is clear that the Journal of Economics and Finance is featured in both bases, but it has only one publication in the Bibliographic Portfolio, being also important to note that some journals appear only in one of the bases, showing that only 4 appear in both.

\section{Conclusions}

The present research sought to answer the following question: how to select references that have high academic relevance and that simultaneously are directly aligned to the context of the management of customer service in a bank in what concern the relationship with customers in the funding and resource loans management activities and perform their bibliometrics, in order to highlight the most prominent authors, articles, periodicals and key words on the subject.

The research question was answered as the search process of scientific articles to form the Bibliographic Portfolio was presented, with 13 articles (Table 1 articles of Bibliographic Portfolio) with scientific recognition, and aligned to the subject banking management of funding and loan of resources, with emphasis on the relationship with the customer. The characteristics of these publications were analyzed in terms of the journal relevance, the recognition of scientific articles, the most prominent authors, the most used keywords, and the impact factor of the journals.

The selection of the Bibliographic Portfolio was carried out in three stages:

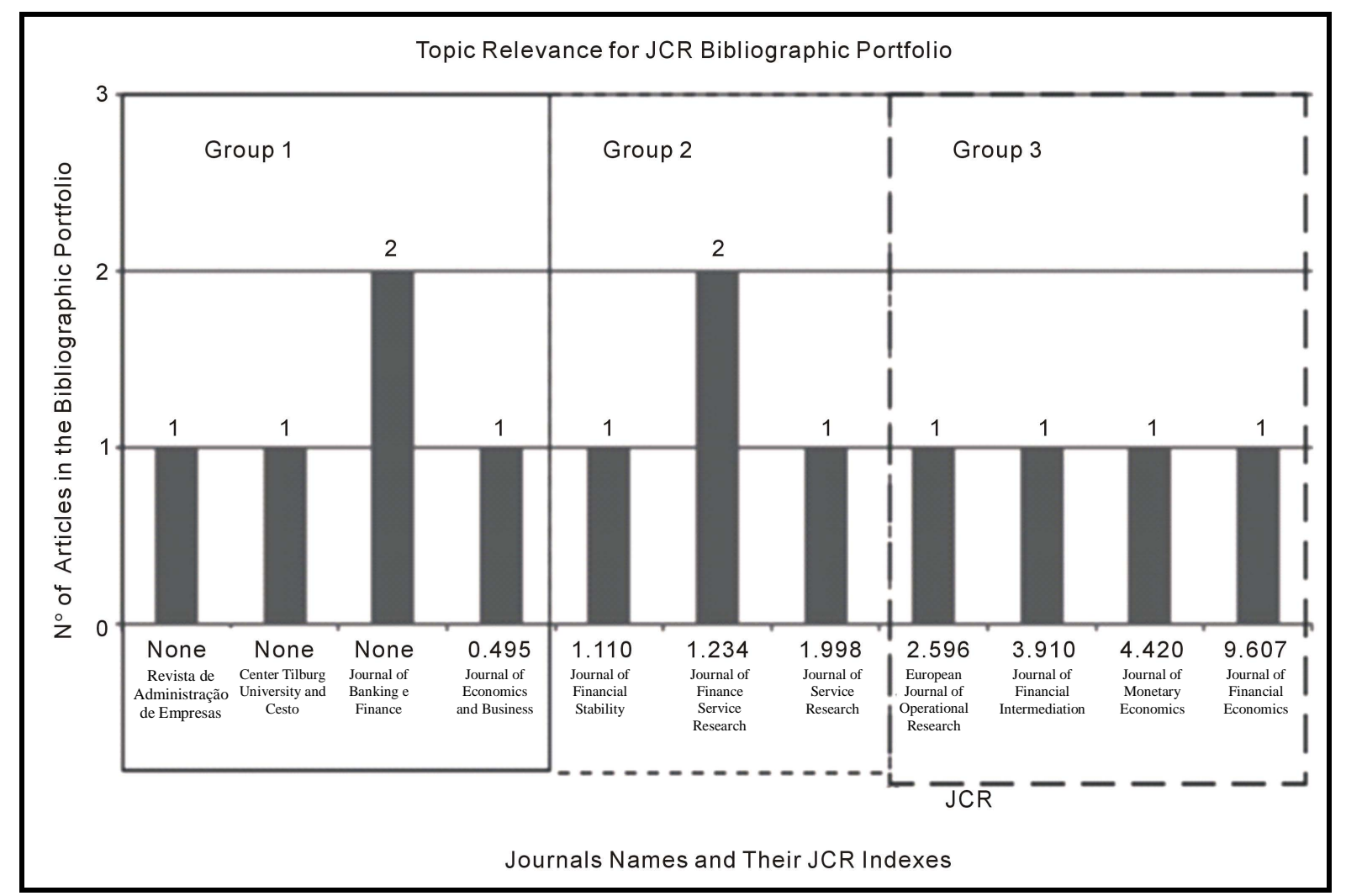

Graph 5. Journals that had impact factor with their rates and number of citations in BP. Source: elaborated by the authors with the survey data, 2013. 


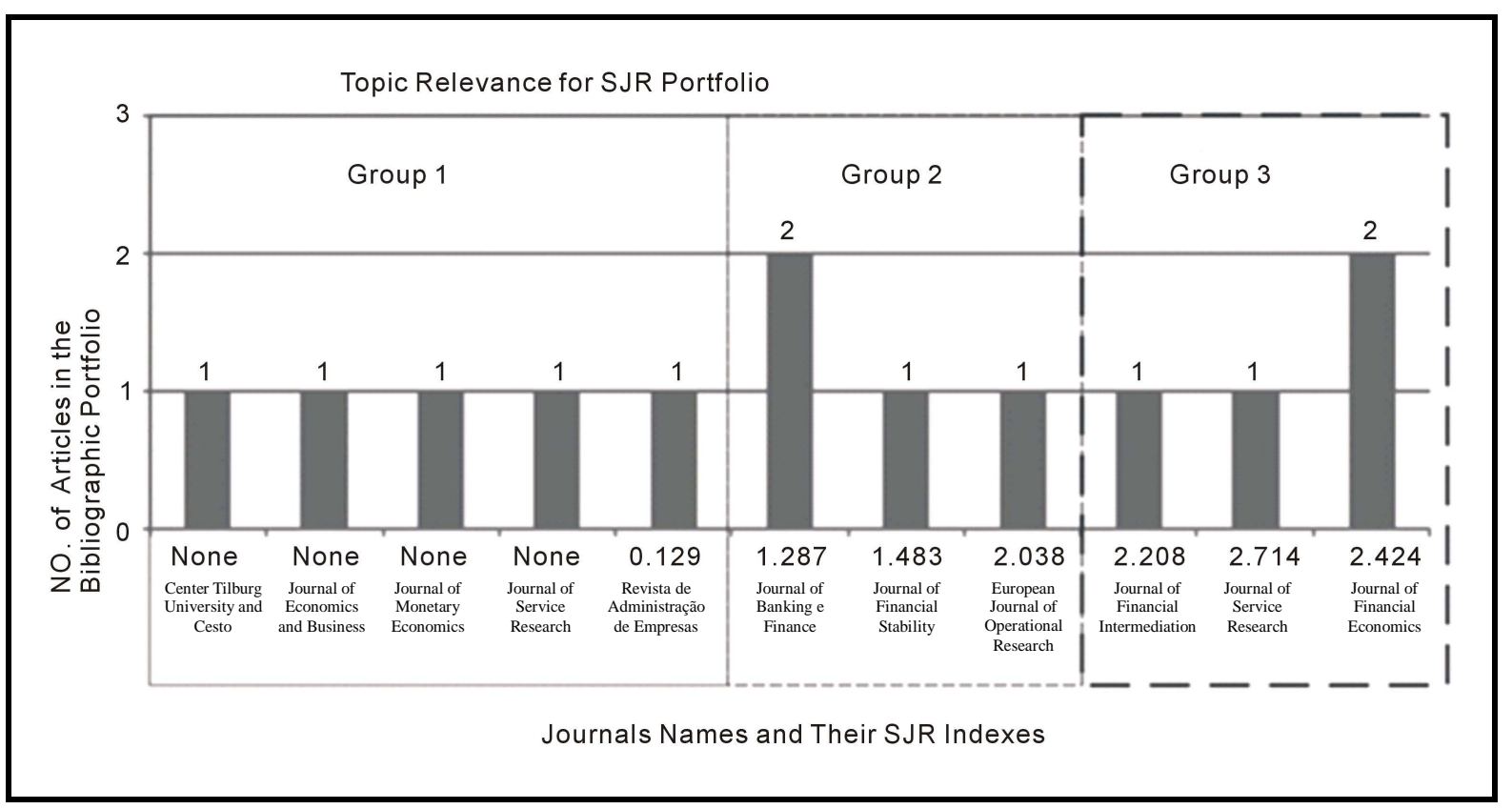

Graph 6. Journals that had impact factor with their rates and number of citations in BP. Source: elaborated by the authors with the survey data, 2013.

- Selection of the raw portfolio of articles in database: held in the databases of CAPES, ISI Web of Science and SCOPUS (Elsevier). From the research axes that defined the subject and from the selected keywords, it was possible to select 12,753 articles that form the Raw Portfolio of articles.

- Filtering the articles database: the Raw Portfolio of articles was analyzed for redundancy, the alignment of the title, scientific recognition (number of citations in Google Scholar), alignment of the abstract, and the alignment of the full article. At the end, 12 articles were selected.

- Representativeness test: with the purpose of verifying the completeness of the obtained portfolio, its references were analyzed and it was found that the articles of Elyasiani, Elyas; Goldberg, Lawrence. Relationship lending: a survey of the literature. Journal of Economics and Business, 2004, with 187 citations, should be added. Therefore, the composition of the Bibliographic Portfolio-BP is concluded with 13 articles.

From the 13 articles (Table 1 articles of the Bibliographic Portfolio) that comprise the selected bibliographic portfolio and from the 344 articles that make up their references, its main quantitative parameters were evidenced.

Regarding the journals, the Journal of Financial Economics was highlighted as the most present one, taking into consideration the 2 articles published by this journal, in BP. In the references, the Journal of Financial was highlighted with 26 publications; and, analyzing the impact factor, the most relevant is the Journal of Financial Economics again, with higher rates in the two searched databases, JCR and SJR (Graph 3 and Graph 4).

In relation to scientific recognition of articles in the Bibliographic Portfolio, the Bank Governance, Regulation and Risk Taking, written by Luc Laeven and Ross Levine, was the most relevant article, with 578 citations in Google Scholar. Among the articles of the references listed in BP, the work The Theory of Bank Risk Taking and Competition Revisited, written by J. H. Boyd and G. De Nicoló, was the most highlighted, with 631 citations.

Among the authors, Degryse stands out, with two publications present in Bibliographic Portfolio. In the references of Bibliographic Portfolio J. P. Hughes stands out, with three articles. The author L. Laeven is the only one that appears in the references with a work of 2001 and, in Bibliographic Portfolio, with an article from 2009. An explanation for this reduced number of authors of Bibliographic Portfolio in references may be associated with the recency of this subject treatment, in research regarding its management, in addition to the lack of a current of thought that appreciates and highlights the subject.

The item evaluates that the most used set of keywords, which had the largest representation, were Bank, Risk and Lending Outcomes. Of these three, two were chosen by the author at the beginning of the survey, which 
represents the adhesion in the choice with the subject to be studied.

Taking into account the boundaries of the research regarding the search locations of articles and journals available in ISI and Scopus databases, in its entirety, the authors of this study, on the basis of the knowledge acquired during the formation of the research process, believe that the results generated can contribute to the scientific community as a result of the use of a structured process, which identified and selected articles aligned to research subject and relevance in academic circle.

It is suggested for future studies: 1) replication of the process for other databases, and expanding the search to annals and congress, theses, dissertations and books, as well as the search for more data bases provided by CAPES; 2) the continuity of the study for the development of the two remaining steps of ProKnow-C, systemic analysis and identification of scientific opportunities for research, with suggestion of new questions and new studies.

\section{References}

[1] Amorin Neto, A.A. and Carmona, C.U.M. (2004) Modelagem do risco de crédito: um estudo do segmento de pessoas físicas em um banco de varejo. Revista Eletrônica de Administração, 10, 4.

[2] Crook, J.N., Edelman, D.B. and Thomas, L.C. (2003) Recent Developments in Consumer Credit Risk Assessment. European Journal of Operational Research, 18, 1447-1465.

[3] De Jonghe, O.V. and Rudi, V. (2008) Competition versus Efficiency: What Drives Franchise Values in European Banking? Journal of Banking \& Finance, 32, 1820-1835. http://dx.doi.org/10.1016/j.jbankfin.2007.12.009

[4] Dean, A.M. (2007) The Impact of the Customer Orientation of Call Center Employees on Customers’ Affective Commitment and Loyalty. Journal of Service Research, 10, 161-173. http://dx.doi.org/10.1177/1094670507309650

[5] Degryse, H. and Ongena, S. (2007) The Impact of Competition on Bank Orientation. Journal of Financial Intermediation, 16, 399-424. http://dx.doi.org/10.1016/j.jfi.2007.03.002

[6] Degryse, H. and Ongena, S. (2008) Competition and Regulation in the Banking Sector: A Review of the Empirical Evidence on the Sources of Bank Rents. Handbook of Financial Intermediation and Banking.

[7] Distinguin, I., Rous, P. and Tarazi, A. (2006) Market Discipline and the Use of Stock Market Data to Predict Bank Financial Distress. Journal of Financial Services Research, 30, 151-176. http://dx.doi.org/10.1007/s10693-0016-6

[8] Elyasani, E. and Goldberg, L. (2004) Relationship Lending: A Survey of the Literature. Journal of Economics and Business, 56, 315-330. http://dx.doi.org/10.1016/j.jeconbus.2004.03.003

[9] Gertler, M., Kiyotaki, N. and Queralto, A. (2012) Financial Crises, Bank Risk Exposure and Government Financial Policy. Journal of Monetary Economics, 59, 517-534. http://dx.doi.org/10.1016/j.jmoneco.2012.11.007

[10] Cebenoyan, A.S. and Strahan, P.E. (2004) Risk Management, Capital Structure and Lending at Banks. Journal of Banking and Finance, 28, 19-43. http://dx.doi.org/10.1016/S0378-4266(02)00391-6

[11] Albertazzi, U. and Gambacorta, L. (2009) Bank Profitability and the Business Cycle. Journal of Financial Stability, 5, 393-409. http://dx.doi.org/10.1016/j.jfs.2008.10.002

[12] Medina, R.P.M. and Selva, M.L. (2013) Credit Scoring Analysis. Revista de Administração de Empresas, 53, $303-315$. http://dx.doi.org/10.1590/S0034-75902013000300007

[13] Gosling, M. and Gonçalves, C.A. (2003) Relacionamento em bancos comerciais: A adaptação de escalas. Revista Eletrônica de Administração, 9, 1-24.

[14] Engelberg, J., Gao, P. and Parsons, C.A. (2012) Friends with Money. Journal of Financial Economics, 103, $169-188$. http://dx.doi.org/10.1016/j.jfineco.2011.08.003

[15] Tasca, J.E., Ensslin, L., Ensslin, S.R. and Alves, M.B.M. (2010) An Approach for Selecting a Theoretical Framework for the Evaluation of Training Programs. Journal of European Industrial Training, 34, 631-655. http://dx.doi.org/10.1108/03090591011070761

[16] Ensslin, L., Ensslin, S.R. and Pacheco, G.C. (2012) Um estudo sobre segurança em estádios de futebol baseado na análise da literatura internacional. Perspectivas em Ciência da Informação, 17, 71-91. http://dx.doi.org/10.1590/S1413-99362012000200006

[17] Ensslin, S.R., Ensslin, L., de Oliveira Lacerda, R.T. and de Souza, V.H.A. (2014) Disclosure of the State of the Art of Performance Evaluation Applied to Project Management. American Journal of Industrial and Business Management, 4, 677-687. http://dx.doi.org/10.4236/ajibm.2014.411073

[18] Rosa, F.S., da Ensslin, S.R., Ensslin, L. and Lunkes, R.J. (2011) Gestão da evidenciação ambiental: Um estudo sobre as potencialidades e oportunidades do tema. Engenharia Sanitária e Ambiental, 16, 157-166. http://dx.doi.org/10.1590/S1413-41522011000200009 
[19] Azevedo, R.C., de Oliveira Lacerda, R.T., Ensslin, L., Jungles, A.E. and Ensslin, S.R. (2013) Performance Measurment to Aid Decision Making in the Budgeting Process for Apartment-Building Construction: Case Study Using MCDA-C. Journal of Construction Engineering and Management, 139, 225-235. http://dx.doi.org/10.1061/(ASCE)CO.1943-7862.0000587

[20] Azevedo, R.C., Ensslin, L. and Jungles, A.E. (2014) A Review of Risk Management in Construction: Opportunities for Improvement. Modern Economy, 5, 367-383. http://dx.doi.org/10.4236/me.2014.54036

[21] Marconi, M.A. and Lakatos, E.M. (2006) Fundamentos De Metodologia Cientifica. Atlas, São Paulo.

[22] Afonso, M.H.F., Souza, J.V., Ensslin, S.R. and Ensslin, L. (2012) Como Construir conhecimento sobre o tema de pesquisa? Aplicação do processo Proknow-C na busca de literatura sobre avaliação do desenvolvimento sustentável. Revista de Gestão Social e Ambiental, 5, 47-62. http://dx.doi.org/10.5773/rgsa.v5i2.424

[23] Bortoluzzi, S.C., Ensslin, S.R., Ensslin, L. and Valmorbida, S.M.I. (2012) A Avaliação de desempenho em redes de pequenas e médias empresas: Estado da arte para as delimitações postas pelo pesquisador. RevistaEletronica de Estratégias e Negocios, 4, 202-222.

[24] de Oliveira Lacerda, R.T., Ensslin, L., Ensslin, S.R. and Dutra, A. (2014) Research Opportunities in Strategic Management Field: A Performance Measurement Approach. International Journal of Business Performance Management, 15, 158-174. http://dx.doi.org/10.1504/IJBPM.2014.060165

[25] Lakatos, E.M. and Marconi, M.A. (2008) Metodologia científica: Ciência e conhecimento científico; métodos científicos; teoria, hipóteses e variáveis. Atlas, São Paulo.

[26] Laeven, L. and Levine, R. (2009) Bank Governance, Regulation and Risk Taking. Journal of Financial Economics, 93, 259-275. http://dx.doi.org/10.1016/j.jfineco.2008.09.003

[27] Schlottfeldt, C.L. and Galli, O.C. (2006) Exigência mínima de capital e rentabilidade: Uma análise empírica dos bancos brasileiros. Revista Eletrônica de Administração, 54. http://hdl.handle.net/10183/4304

[28] Gil, A.C. (1991) Como Elaborar Projetos de Pesquisa. Atlas, São Paulo.

[29] Richardson, R.J. (1999) Pesquisa social: Métodos e técnicas. Atlas, São Paulo.

[30] Bruna Jr., E.D., Ensslin, L. and Ensslin, S.R. (2012) Seleção e análise de um portfólio de artigos sobre avaliação de desempenho na cadeia de suprimentos. Gestão da Produção, Operações e Sistemas, 7, 113-125

[31] Bruna Jr., E.D., Ensslin, L. and Ensslin, S.R. (2014) An MCDA-C Application to Evaluate Supply Chain Performance. International Journal of Physical Distribution \& Logistics Management, 44, 597-616. http://dx.doi.org/10.1108/IJPDLM-05-2012-0157

[32] Longaray, A.A. and Ensslin, L. (2014) The Usage of MCDA in Identification and Measurement of Criteria Performance for Certification of Public Teaching Hospitals in Brazil. Production, 24, 41-56.

[33] Bruna Jr., E.D., Ensslin, L. and Ensslin, S.R. (2011) Supply Chain Performance Evaluation: A Case Study in a Company of Equipment for Refrigeration. Proceedings of the Technology Management Conference of the IEEE International, San Jose, 27-30 June 2011, 969-978.

[34] Marafon, A.D., Ensslin, L., de Oliveira Lacerda, R.T. and Ensslin, S.R. (2015) The Effectiveness of Multicriteria Decision Aid Methodology: A Case Study of R\&D Management. European Journal of Innovation Management, 18, 86-109. http://dx.doi.org/10.1108/EJIM-10-2013-0106 